Fig. I), and this lasted all day, with the addition at 4 P.M. till 5.40 P.M. of the arc $\iota k$ (being the exact copy of Fig. 4 of March 20) ; at 6 P.M. there was the ordinary circle $\alpha \beta$, the mock sun $\gamma$, and an inverted portion $\eta \theta$ (Fig. 2). At 6. ro only the ordinary halo remained.

From 8 P.M. till 9.40 P.M. (2rst) there was a lunar balo with

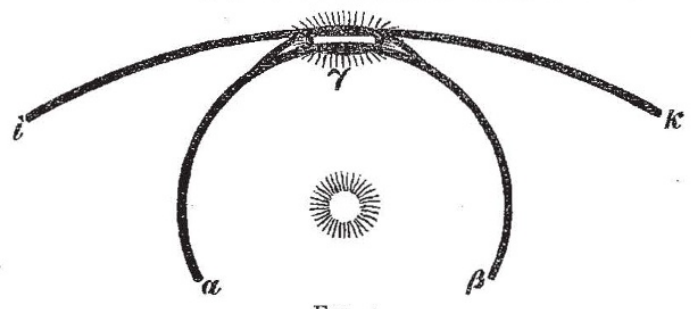

FIG. 4.

an elongated mock moon; so that a similar condition of the atmosphere prevailed for thirty-eight hours.

Whenever the circles were briliant, they were formed in a very thin haze-like cloud, through which the sun or moon (in either case) shone brightly.

The weather was cold with thick ice in the morning.

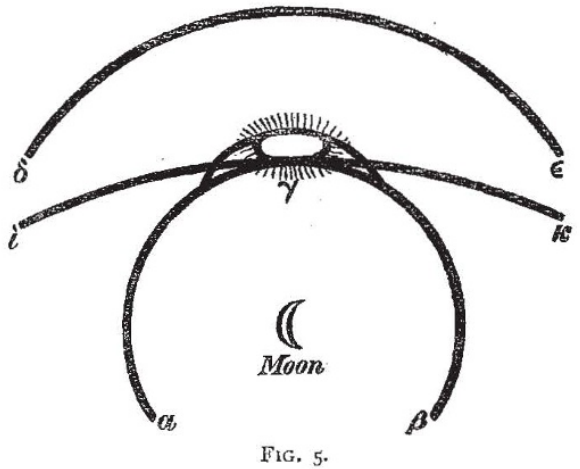

At 8 A.M. on the 20 th the sky was scattered over with thin woolly cirri, indistinct in outline, and dirty-white in colour, with here and there a small prominent white portion (the sky resembling a sea with a few white wave-crests here and there). These clouds moved in a south current, but at 9 A.M. the clouds were again floating in a north. east current.

The wind on the 2oth was north-east, and on the 2 Ist north.

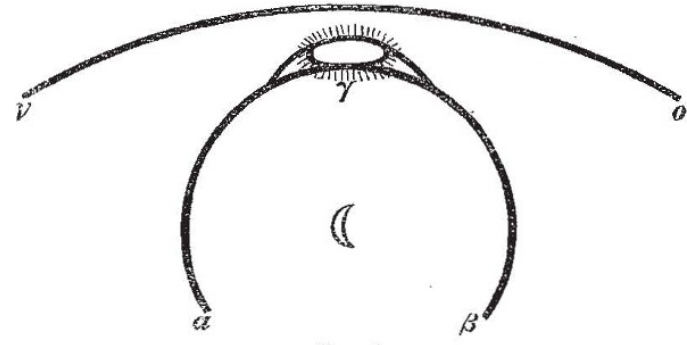

Fig. 6.

\begin{tabular}{|c|c|c|c|c|c|c|}
\hline $\begin{array}{l}\text { Femper } \\
\text { ture on }\end{array}$ & Dry & Vet bulb. & $\begin{array}{c}\text { Tempera- } \\
\text { ture on } \\
\text { 2Ist. }\end{array}$ & & Dry bulb. & \\
\hline M. & & ... $3 \mathrm{I}^{\circ} \mathrm{O}$ & 8 A.M. & $\cdots$ & 35 & ... $32 \cdot 7$ \\
\hline & ... $4 x^{\circ} 9$ & .. $34^{\circ} \mathrm{O}$ & I P.M. & $\cdots$ & 42 & .. 3 \\
\hline 6 & .. $37 \% 5$ & ‥ 34 & 6 P.M. & $\cdots$ & 7 & $\cdots$ \\
\hline I. P. & 32.8 & .. 3 & I I P.M. & $\cdots$ & $30^{\circ} 0$ & \\
\hline
\end{tabular}

II P.Malo and lunar halo.

$$
\begin{array}{llll}
" & 23, & & \\
, & 27, & & \\
, & 28, \text { solar halo. } & & \\
, & 30, \text { lunar halo. } & & \text { E. J. Low E }
\end{array}
$$

\section{Owens College}

IT seems probable that the claims of Owens College to be constituted into a university and degree-giving body for the north of England, will soon be brought before the public in a more definite shape than that of newspaper correspondence. There are one or two considerations affecting the question, which do not seem to me to have been brought forward by any of those who have entered into the discussion, and I shall esteem it a favour if you will allow me briefly to notice these.

I may premise that no word in this letter is intended to derogate from any claims that Owens College may advance on the ground of past or prospective services to education in the district of England to which its efforts must be principally, though not entirely, confined. It is almost impossible to over-rate those claims, but when they are so put forward as to imply that Owens College is the only possible centre for giving degrees in the north of England, the dwellers on the banks of the Tyne, the Wear, and the Tees, are apt to feel that too little account is made both of the necessities and of the actual educational resources of their own part of the " north of England."

In the first piace, a careful study of Bradshaw makes it clear that, for the counties of Durham and Northumberland, and even the north-east portion of Yorkshire, a university examination or college course is at least as accessible in London as at Manchester; so that for these counties the benefits of Owens College, whether as college or university, are practically on a par with those of University College, London, and the degree examinations of the University of London.

Secondly, it is a fact, although apparently unknown to the majority of those who have written on this question, that there already exists in the north of England--at Durham--a university with a Royal Charter for giving degrees in all faculties, and whose conditions for giving those degrees combine in an admirable manner the modern spirit with the strictness of the old requirements.

This university was originally founded by the liberality of the Cathedral authorities, who, with a spirit worthy of imitation elsewhere, set apart certain of their own funds for the purpose of giving a liberal eaucation in arts and theology to students who for various reasons could not avail themselves of the advantages of Oxford and Cambridge. As always happens in such cases, benefactions of scholarships and fellowships have accrued which have considerably increased the funds available for educational purposes.

Nor have these funds been restricted, as many might expect, looking at the source from which they come, to sectarian purposes. While most of the colleges at Oxford and Cambridge were still compelling Jews and Nonconformists to attend reli. gious services to which they objected, the regulations of the University of Durham anticipated the Universities' Tests Act by granting exemption in such cases; and during the last six years more than a thousand pounds a year of the university funds has been set aside for the purposes of the Science Faculty of the university which has its local habitation in Newcastle.

$I$ may add that the Senate and Convocation of the university have in late years adopted a most liberal view in regard to the admission of students of other colleges than those at Durham and Newcastle to the degrees which they give, and I have personally little doubt that they would consider with favour any scheme for extending the area over which their degrees are available.

The question of the desirability of multiplying the number of centres for giving degrees is a wide one, into which I have no desire to enter. My only wish is that in any consideration of the question of establishing a new centre, all the facts regarding its sphere of action and the centres which already exist within what is claimed as that sphere should be known.

College of Physical Science, Newcastle- ST-Tyne, March 24

\section{The Suspected Intra-Mercurial Planet; Occultation of Kappa Geminorum}

MARCH 2 I was fine here, but with frequent clouds. I had several observations of the sun from 9 o'clock to 12, Dublin mean time, and then at $12.35,1.35,2.0$, and 3.50 , after which the sun become permanently clouded for the remainder of the day. The only object remarked was a small spot with a double nucleus near the western limb followed by a few very small spots.

March 22 was finer, and I observed at 8.30, 9.12, 10.20, I0. $50,11.25,12.38,1.35$, I. $50,2.55,4.25,5.8$, and 5.33 . The small spots of the previous day had completely disappeared, and broad bright lacunæ occupied their place. The large spot 